\title{
Innovation Research on Ideological and Political Education in Colleges and Universities Based on New Media Vision
}

\author{
Nuofeng Li \\ Xi'an Aeronautical Polytechnic Institute \\ Xi'an 710089 China
}

\begin{abstract}
Due to the progress of society in recent years, new media has become the main means of information acquisition and interaction in the system of colleges and universities, and meanwhile the gradual development of new media also has impacts on the ideological and political education in colleges and universities. In addition to analyzing effects of new media on the ideological and political education in colleges and universities, the author makes an innovative thinking from the aspects of building the working platform for ideological and political education, enriching the contents of education, perfecting the methods of education and improving the quality of educational staff. This paper aims to provide reference for the relevant educators.
\end{abstract}

Keywords—new media; colleges and universities; ideological and political education; innovative measures

\section{INTRODUCTION}

New media is a form of media based on Internet technology, mobile communication technology and digital technology, which provides information or related services to readers through some common terminals. With the help of a variety of equipment and application software, the new media now has become the main form of university internal students to obtain and exchange information, by virtue of its own massive information flow, portable use and good man-machine interactive experience. In this context, carrying out ideological and political education through the new media has become the mainstream choice of many colleges and universities.

\section{THE INDIVIDUAL FUNCTION OF NEW MEDIA TO THE IDEOLOGICAL AND POLITICAL EDUCATION IN COLLEGES AND UNIVERSITIES}

New media has a multifaceted role in ideological and political education in colleges and universities. It is important for us to recognize its positive aspects, so as to realize that the important significance of "new-media-oriented development" in ideological and political education. It is also necessary to recognize the possible negative impacts and then play the due role of new media in the ideological and political education [1].

On the one hand, the new media is a new carrier of ideological and political education in Colleges and universities. Its interaction and equality as well as the efficient and compatible means of communication can strengthen the communication between teachers and students, which avoids the monologue education while gradually forming a multisubjective communication model. This can fully stimulate students' enthusiasm for learning, so that they can actively participate in relevant educational activities and ideological and political education can give full play to its expected effects. For example, it allows students to present personal opinions on major social issues during the free discussion and allows them to comment or debate on some hot topics. This can guide students to resonate with positive views and thereby extends the achievement of ideological and political education.

On the other hand, there are differences in human logic between new media and ideological and political education. Specifically, the new media is more targeted at the economic efficiency of enterprises. Its main objective is to meet the requirements of consumers and complete the optimal allocation. The humanistic education in colleges and universities mainly emphasizes the cultivation of students in the value system, mode of thinking, habits and other aspects. Its essence is not to cater, but to guide students and respect for their autonomy. In this respect, the new media inevitably has conflicts with ideological and political education in some aspects. Thus, how to exert advantages while reducing disadvantages has become the work focus of educators.

Generally speaking, the popularization of new media provides a completely new requirement for the development of ideological and political education in Colleges and universities. This new mode of information communication has exerted a subtle influence on college students in various aspects, including their values, modes of thinking, political views and moral standards. Ideological and political education in colleges and universities is to further improve the ideological height and political quality of college students. However, a lot of colleges and universities are still using traditional methods and ideas. They do not have a good understanding of the characteristics and the role of the new media, and thus do not keep pace with the times in the ideological and political education. As the result, the present ideological and political education in some colleges and universities is featured by less actual effects, weak pertinence and poor adaptability. In order to solve this problem, educators should grasp the key problems and start with the renewal of educational ideas. In addition, in terms of the teaching method, it is needed to organically combine the new mode with traditional effective ways widely accepted, so as to 
create a new image of ideological and political education and then play the due utility of education [2].

\section{The InNOVATIVE Methods OF IDEOLOGICAL AND POLITICAL EDUCATION IN COLLEGES AND UNIVERSITIES FROM THE PERSPECTIVE OF NEW MEDIA}

\section{A. Enriching the Content of Ideological and Political Education}

In the context of the new media era, college students can obtain information of various events in different regions on the Internet. They can also know some hot events and hot topics in details the first time. These kinds of information exchange platforms, which consists of the new media applications, social networking platform and portals, allow college students to participate in the discussion on the basis of obtaining information and support them to show personal specific comments by the way of post and reply. This has made great differences in the development and freedom of official information publicity channels. Within the university system, the colleges and universities themselves are the source of information disclosure, and all comments need to be reviewed to ensure that there is no content that does not meet the main melody or is bias. This thus makes its publicity and the actual effect of information dissemination be greatly reduced, which is not conducive to information interaction on some topics among students and the school. In this regard, the ideological and political education in colleges and universities in the new media era must be integrated into the new environment and adapt to the existing way of information exchange. On the basis of strengthening the basic conditions, colleges and universities should pay more attention to strengthen the content construction of the new media working platform and enrich the platform contents, so as to attract the attention of college students and guide them to pay attention to the ideological and political education. This is the only way which can promote the information exchange between the school and those educated, eliminate the ideological exchange gap and ensure the smooth development of ideological and political education.

Three aspects should be taken into account to enrich contents of the ideological and political education working platform. First of all, due to the development of information technology and the popularity of mobile networks, the contents of ideological and political education in colleges and universities should be more comprehensively networked, rather than simply confined to oral teaching, teaching materials and other means. Only by applying the network transformation on relevant contents can the information presented online deliver through the way suited to network communication. And only by this way can the ideological and political education complete its new-media-oriented development to fully adapt to the new characteristics of the times. Secondly, in view of the increasing attention of college students to hot social spots, schools should conduct a collation of network public opinions and give rigorous responses to some important issues in a timely manner. At the same time, the school should refute extreme or even wrong views timely to guide students to have objective and comprehensive understanding of problems. This will help college students gradually form relatively correct values in the discussion and exchange about hot issues. Finally, some methods can be employed to apply a series of subject ability training on college students, such as selecting normal national textbooks. While playing the role of teaching materials and books, educators can combine some social focuses or difficult problems with classroom teaching, making teaching contents become profound and hierarchical [3].

\section{B. Innovating the Working Methods of Ideological and Political Education in Colleges and Universities}

In this era of information explosion, the form for many college students to get information has transformed from the passive "acceptance" to active search. In other words, college students have relatively high autonomy in the process of obtaining and processing messages. The ideological and political education in colleges and universities needs to respect ways in which students think independently in such a big environment. In the work, a new attitude of ideological and political education more equal and objective and new education methods should be used to seize the attention of students, helping them realize that the traditional one-way "spoon-fed" model of ideological and political education has been changed. In this process, they will also understand that their dominant role is gradually recognized. At the same time, colleges and universities should pay more attention to cultivating students' independence ability, so that students can acquire and exchange information with right ways [4].

Specifically, colleges and universities can achieve the method innovation of ideological and political education from two aspects. On the one hand, colleges and universities should change the traditional cramming education and adopt some innovative teaching methods which can improve students' concentration, such as discussion-based learning, project-based learning, case-based learning, and so on. This can motivate students' initiative in teaching activities and guide them to sum up their own ideas and make active speeches, so that the classroom interaction between the teachers and students can be strengthened and students can improve self-awareness in the learning process. On the other hand, the assessment form of relevant courses should be changed. The traditional assessment of students is simply the examination of knowledge students have learned, rather than evaluation of their political quality and ideological ways. That is to say, the examination evaluation should be transformed to comprehensive evaluation of students, so as to evaluate the achievements of ideological and political education. Generally speaking, colleges and universities can encourage their students to participate in social practice and volunteer work, so that students can gain more knowledge in the practice. Teachers can also affirm students' achievements by selecting outstanding student representatives and models of student activity, so that students can form thinking patterns and habits which are more mature in the subconscious.

\section{Improve the Quality of the Ideological and Political Education Team and Optimizing the Work System}

At present, the ideological and political education work in colleges and universities also poses increasingly high demand on the overall quality of the education team. It should be 
attributed to that the application of new media requires a high professional competence and relatively complete professional knowledge system, because the new media itself is an integration of the network technology, audio and video technology, digital technology, information technology and other technical means. Therefore, the implementation of ideological and political education in colleges and universities needs a professional talent team. However, many ideological and political educators present do not well adapt to new things, so that they do not have strong technical knowledge of the network to support the construction of ideological and political education platform and also not have skills to communicate with college students at the network level. This also makes many students do not have a good understanding of the ideological and political education and not maintain high sensitivity to the content of education, thus directly affecting the effect of ideological and political education.

Colleges and universities can carry out the construction of ideological and political education from two aspects: the construction of work system and improvement of team quality. In the construction of the work system, colleges and universities should fully consider the rationality of the existing ideological and political education framework and organize relevant personnel to set up a new media office for ideological and political education, focusing on the work of the relevant educational departments on the ideological and political education online. It is also important to provide technical support for the collection, production, management, distribution and maintenance of new media materials. To improve the team quality, colleges and universities should offer workshops and training of the new-media-oriented ideological and political education, aiming at collecting the information technology and network knowledge that the new media needed and focusing on the application of knowledge training. These methods can improve the professionalism of ideological and political educators in colleges and universities, and realize the organic combination of new media application and ideological and political education. In addition, for the relevant ideological and political education, the construction and cultivation of work force should not be limited to internal staff. To some students having strong professional knowledge and basic literacy in the new media, their dominant role should be enlarged. They should be supported to integrate themselves into the corresponding contents of ideological and political education through their favorite ways like WeChat Public Account and live web casting, so as to achieve the transformation from theory to application. This can enhance students' interest in learning relevant contents and enrich their access to ideological and political education, so that they can create a series of campus new media sites for student selfmanagement and self-education with their own strength.

\section{Constructing the New Media Platform of Ideological and Political Education}

The implementation of ideological and political education in colleges and universities cannot be confined in the colleges and universities, but should be based on the social basis, allude to the social reality and full of social thinking. The new media is a kind of media form which can effectively realize the combination of virtual network environment and the actual public environment. Therefore, the full understanding of it will help the ideological and political educators in colleges and universities fully recognize its external environment. Based on this consideration and social environment of new media, colleges and universities should organize relevant staff to play personnel and technical advantages, integrate new media technology and make use of new media tools, achieving the diversification and efficiency of ideological and political education means. This requires colleges and universities to grasp the mechanism of new media in the process of education implementation and build a new media platform for the ideological and political education according to the principle of online and offline information mutual communication.

In the construction of new media platform, relevant personnel should get out of fixed thinking and treat with problems with an open view. First of all, during the construction of the platform, colleges and universities should integrate and transform the existing educational resources and display the abstract text materials as much as possible by video or picture materials more appealing and more influential. In this way, learners can integrate into the scene of ideological and political education and benefit in the atmosphere of newmedia-oriented ideological and political education. Secondly, special attention should be given to the influence of education brand. Colleges and universities should build a number of modern network-based ideological and political education projects to create the brand effect, and gradually develop its social influence, so as to deepen the educational connotation and make the educational content become more popular. Finally, special functions of new media in information interaction should be highlighted to realize the convenient communication between educators and those being educated. At the same time, the platform should be widely used to listen to the views of students and respond to their demands, so that ideological and political education in colleges and universities can have better practical significance.

\section{CONCLUSION}

The new media has realized the freedom of information interaction, providing the college students with a carrier to collect information, exchange and express their viewpoints. The ideological and political education in colleges and universities should make great progress on the basis of fully understanding the role of new media and combine with the experience of new media, so as to expand the educational contents, innovate the educational means and build new media platforms. And meanwhile, colleges and universities should attach great importance to the improvement of the overall quality of teachers and adopt a multi-pronged approach to exert the advantage of new media in the ideological and political education, so as to ensure the expected results of education and cultivate more high-quality personnel for China's socialist modernization. 


\section{REFERENCES}

[1] Yan Haixia. Research on the Reform and Innovation of Ideological and Political Education in Colleges and Universities from the Perspective of New Media [J]. Human Resources Development, 2016. 04: 214.

[2] Chen Yunling. Reform and Innovation of College Ideological and Political Education in the Era of New media [J]. Journal of Hunan University of Science and Engineering, 2016. 08: 38-39.
[3] Cao Wei, Dong Lina. Analysis of Ideological and Political Education Innovation in Colleges and Universities from the Perspective of New Media [J]. New West, 2016. 20: 113-114.

[4] Wang Li. Model Remodeling of Ideological and Political Education in Colleges and Universities from the Perspective of Micro-media [J]. Journal of Chongqing University of Science and Technology, 2016.11: $101-102+117$. 